\title{
ETHANOLIC EXTRACT OF TITHONIA DIVERSIFOLIA (HEMSLEY) A. GRAY INHIBITS MIGRATION ACTIVITY AND DECREASE THE TRANSFORMING GROWTH FACTOR-BETA1, VEGF EXPRESSION ON KELOID FIBROBLASTS
}

\author{
MAE SRI HARTATI WAHYUNINGSIH ${ }^{1,3 *}$, DWI ARIS AGUNG NUGRAHANINGSIH ${ }^{1,3}$, ARIEF BUDIYANTO² \\ ${ }^{1}$ Department of Pharmacology and Therapy, Faculty of Medicine Public Health and Nursing, Universitas Gadjah Mada, Indonesia, Sekip \\ Utara, Yogyakarta 55281. ${ }^{2}$ Departement of Dermatology and Venerology, Faculty of Medicine Public Health and Nursing, Universitas \\ Gadjah Mada, Yogyakarta, Indonesia. ${ }^{3}$ HerbaL Medical Center, Faculty of Medicine Public Health and Nursing, Universitas Gadjah Mada, \\ Indonesia. E-mail: maeshw98@gmail.com
}

Received: 19 July 2018, Revised and Accepted: 9 November 2018

\section{ABSTRACT}

Objectives: Keloid occurred due to abnormal wound healing, characterized by massive fibroblast proliferation and excessive collagen accumulation. Tithonia diversifolia Hemsley A. Gray has been known to show antiproliferative effect against some cancer cells in vitro. However, its potential as antikeloid has not been explored. This study aims to assess the T. diversifolia ethanolic extract effect on fibroblast migration activity, transforming growth factor-beta1 (TGF- $\beta 1$ ), and vascular endothelial growth factor (VEGF) expression of keloid fibroblasts in vitro.

Methods: Fibroblasts were isolated from keloid collected from patient keloid tissue. The migration activity of keloid fibroblasts was assessed using scratch assay. The TGF- $\beta 1$ and VEGF expression examination was done using ELISA.

Results: Ethanolic extract of T. diversifolia treatment at a concentration of $20 \mu \mathrm{g} / \mathrm{ml}, 10 \mu \mathrm{g} / \mathrm{ml}$, and $5 \mu \mathrm{g} / \mathrm{mL}$ for $24 \mathrm{~h}$ on keloid fibroblasts culture showed slower migration activity compare to those on keloid fibroblast culture without treatment $(\mathrm{p}<0.05)$. The TGF- $\beta 1$ and VEGF expression was significantly lower in ethanolic extract of T. diversifolia treatment group compared to those on keloid fibroblast without treatment $(\mathrm{p}<0.05)$.

Conclusion: Ethanolic extract of T. diversifolia inhibits fibroblast migration activity and decrease the expression of VEGF and TGF- $\beta 1$ on keloid fibroblasts in vitro.

Keywords: Keloid fibroblast, Tithonia diversifolia, Migration, Transforming growth factor-beta1, Vascular endothelial growth factor.

(c) 2019 The Authors. Published by Innovare Academic Sciences Pvt Ltd. This is an open access article under the CC BY license (http://creativecommons. org/licenses/by/4. 0/) DOI: http://dx.doi.org/10.22159/ajpcr.2019.v12i1.29850

\section{INTRODUCTION}

Keloid is a fibroproliferation dermal tumor, harmless, that grew in the scar and exceeds the wound limit. In developing countries, there are around 100 million patients who have scarring complaints. Those are giving the impact on physical condition, esthetic, psychological, and social [1,2]. Keloid is characterized by excessive accumulation of extracellular matrix components such as collagen, fibronectin, elastin, proteoglycans and growth factors [3].

Keloid therapy actually has been widely practiced with a variety of side effects that have been reported as long-term therapy with an injection of triamcinolone acetonide and mitomycin C can cause skin atrophy, telangiectasia, and pigmentation disorders [4]. Some studies about keloid have been done, but research on the natural product is still very few. One of the natural ingredients that have been studied is the Tithonia diversifolia (Hemsley) A. Gray. Initial studies on keloids suggested that the standardized ethanol extract of $T$. diversifolia can inhibit keloid fibroblast proliferation and collagen deposit [5]. The active compound of $T$. diversifolia shows cytotoxicity against cancer cells, is Tagitinin $\mathrm{C}$ which is a sesquiterpene lactones class, and was isolated from the leaves of T. diversifolia (Hemsley) A. Gray using a bioassay-guided isolation method ( $(3-(4,5-$ dimethylthiazol2-yl)-2,5-diphenyltetrazolium bromide [MTT] on cells HeLa $\mathrm{IC}_{50} 9.776 \mu \mathrm{g} / \mathrm{mL}$ ) [6]. Tagitinin C proved able to inhibit collagen accumulation on keloid fibroblasts in vitro [7]. Therefore, research on ethanolic extract of T. diversifolia (Hemsley) A. Gray against migration activity and expression of transforming growth factor-beta1 (TGF- $\beta 1$ ) and vascular endothelial growth factor (VEGF) in fibroblast Keloids needs to be studied.

\section{MATERIALS AND METHODS}

Keloid fibroblasts used were a subculture passage III-IV, obtained from the laboratory of health technology, Dermatology Venereology Division, Faculty of Medicine Gadjah Mada University. Materials used were T. diversifolia (Hemsley) A. Gray leaves collected from PakemYogyakarta special district of Indonesia on February 2017, identified at the laboratory plant systematics, and voucher specimen no: 0579/S. $\mathrm{Tb}$./IX/2017 was deposited in laboratory plant systematics, Faculty of Biology, Universitas Gadjah Mada. Amphotericin B-Fungison (GibcoTM), Dulbecco's modified Eagle's medium (Gibco), dimethyl sulfoxide (DMSO) (Merck), Ceftriaxone, fetal bovine serum (Gibco), Formaldehyde 10\% (Gibco), MTT (Sigma), medium Roswell park memorial Roswell park memorial Institute 1640 (Sigma), PenicillinStreptomycin (Gibco BRL), phosphate buffer saline (Gibco), Povidoneiodine 10\% (Gibco), and Trypsin EDTA 0,25\% (Gibco) were used.

\section{Extraction of T. diversifolia}

About $1 \mathrm{~kg}$ of $T$. diversifolia leaves dried powder was macerated by ethanol (70\%) (2 L). The mixture was stirred periodically for $24 \mathrm{~h}$. The filtrate was separated by filtration (Buchner funnel), and maceration was repeated 3 times. The filtrates obtained were combined and evaporated in vacuo to dryness.

\section{The 96 well plate culture preparation}

Cell suspension was counted based on a number of group in the study in triplicate. Fibroblast cell culture harvested, washed, and made into suspension with concentration $2 \times 10^{5} / \mathrm{mL}$ medium. Each well on a plate then filled with $200 \mu \mathrm{L}$ cell suspension and marked according to the research plan. Cells in 96 well plate were incubated in an incubator 
$\mathrm{CO}_{2} 5 \%$, temperature $37^{\circ} \mathrm{C}$ for $24 \mathrm{~h}$. Each work sample requires two plates for fibroblast proliferation and collagen accumulation, 1 plate for $72 \mathrm{~h}$ and 1 plate for 120 incubation time, repeated up to 3 times.

Tested concentration preparation

About $5 \mathrm{mg}$ of the ethanolic extract of $T$. diversifolia was diluted in $100 \mu \mathrm{L}$ DMSO to obtain a stock solution $(50.000 \mu \mathrm{g} / \mathrm{mL})$. Then, 3 series concentrations $5 \mu \mathrm{g} / \mathrm{mL}, 10 \mu \mathrm{g} / \mathrm{mL}$, and $20 \mu \mathrm{g} / \mathrm{mL}$ of the extract were prepared.

\section{Fibroblast migration assessment with scratch assay}

Measurement of cell migration test by in vitro scratch assay method [8] and analyzed by the method used [9] wound creation on culture cell migration was done by scratching the well base using blue tip micro pipet. After the treatment was completed, all groups were incubated for $48 \mathrm{~h}$, but every $24 \mathrm{~h}$ microscopic images were taken using an inverted microscope. The images obtained from each well plate sample were analyzed using Image J software to obtain the percentage of the scratch area. The percentage of cell migration is determined by $100 \%$ - percentage of scratch area.

\section{Measurement of TGF- $\beta 1$ expression}

The protocol of TGF- $\beta 1$ measurement is performed according to the procedure issued by Koma Biotech.inc as a manufacturer of the human TGF- $\beta 1$ measurement kit.

\section{Measurement of VEGF expression}

The protocol of VEGF measurement is performed according to the procedure issued by Koma Biotech.inc as a manufacturer of the human VEGF with Catalog No: K0331132.

\section{Ethics approval of research}

This research has received permission from the Ethics Committee Research Faculty of Medicine, University of Gadjah Mada based eligibility letter conduct, with the number KE/FK/426/EC.

\section{RESULTS AND DISCUSSION}

\section{Fibroblast migration activity}

The mean of keloid fibroblast migration activity is optimal decreased at $24 \mathrm{~h}$ with $10 \mu \mathrm{g} / \mathrm{mL}$ of $T$. diversifolia ethanolic extract treatment. The mean of keloid fibroblast migration activity was lower significantly compare those on other groups are shown in Fig. 1. The ethanolic extract of $T$. diversifolia treatment at a concentration of $20 \mu \mathrm{g} / \mathrm{mL}, 10 \mu \mathrm{g} / \mathrm{mL}$, and $5 \mu \mathrm{g} / \mathrm{ml}$ for $24 \mathrm{~h}$ on keloid fibroblast culture showed slower migration activity compare to those on keloid fibroblast culture without treatment $(\mathrm{p}<0.05)$. There was no difference on keloid fibroblast migration activity among $\mathrm{T}$. diversifolia ethanolic extract treated groups on 48 hours treatment (Fig. 2). These results suggest that the effects of ethanolic extract of $T$. diversifolia on the increase in the number of fibroblast cells of keloid occur inhibition or decrease in migratory activity in keloid cell fibroblasts. This indicates that cell migration activity at $48 \mathrm{~h}$ may close the wound in the scratch area.

The effect of the ethanolic extract of T. diversifolia inhibition on migratory activity of keloid fibroblasts is greater with increased concentration of ethanolic extract of T. diversifolia. This suggests that the administration of the ethanolic extract of T. diversifolia with concentration of $5 \mu \mathrm{g} / \mathrm{mL}$ does not provide the inhibitory effect. However, the difference between the concentration of the ethanolic extract of T. diversifolia and the keloid fibroblast control group was statistically significant $(p<0.05)$.

\section{Measurement of TGF- $\beta 1$ expression}

Ethanolic extract of T. diversifolia on the expression of TGF- $\beta 1$ in keloid fibroblasts is shown in Fig. 3 . This result shows that TGF- $\beta 1$ expression in keloid fibroblasts treatment with an ethanolic extract of $T$. diversifolia was lower compared to those on keloid fibroblast without treatment. The treatment by ethanolic extract of $T$. diversifolia with various concentrations of $5 \mu \mathrm{g} / \mathrm{mL}, 10 \mu \mathrm{g} / \mathrm{mL}$, and $20 \mu \mathrm{g} / \mathrm{mL}$ in keloid fibroblasts has almost similar results shown in Fig. 3. It can be concluded that TGF- $\beta 1$ expression was significantly lower in ethanolic extract of T. diversifolia group compared to those on keloid fibroblast without treatment $(\mathrm{p}<0.05)$.

\section{Measurement of VEGF expression}

Ethanolic extract of T. diversifolia on the expression of VEGF in keloid fibroblasts is shown in Fig. 4. This result shows that ethanolic extract of $T$. diversifolia various concentrations $(20 \mu \mathrm{g} / \mathrm{mL}, 10 \mu \mathrm{g} / \mathrm{mL}$, and $5 \mu \mathrm{g} / \mathrm{mL}$ ) in keloid fibroblasts showed different VEGF expression compare to those on keloid fibroblast control group $(\mathrm{p}<0.05)$. Ethanolic extract of T. diversifolia concentration of $20 \mu \mathrm{g} / \mathrm{mL}$ or which constitute the largest concentration has optimal results when compared to other concentrations of the ethanolic extract of $T$. diversifolia treatment group $(p<0.05)$. The above data corroborate that the treatment with an ethanolic extract of $T$. diversifolia can inhibit cell proliferation

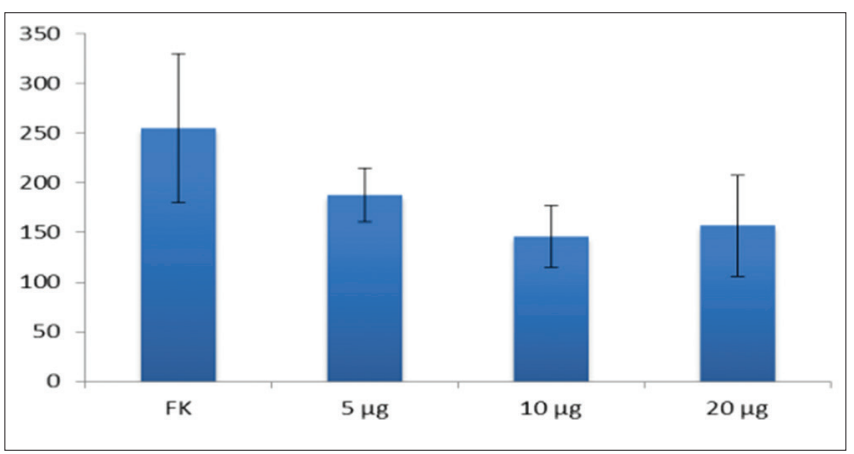

Fig. 1: Effect of T. diversifolia extract on keloid fibroblasts migration activity (\%) at 24 hours. Description: FK = Fibroblasts Keloid, T. diversifolia extract concentration $20 \mu \mathrm{g} / \mathrm{mL} ; 10 \mu \mathrm{g} / \mathrm{mL}$; and $5 \mu \mathrm{g} / \mathrm{mL}$

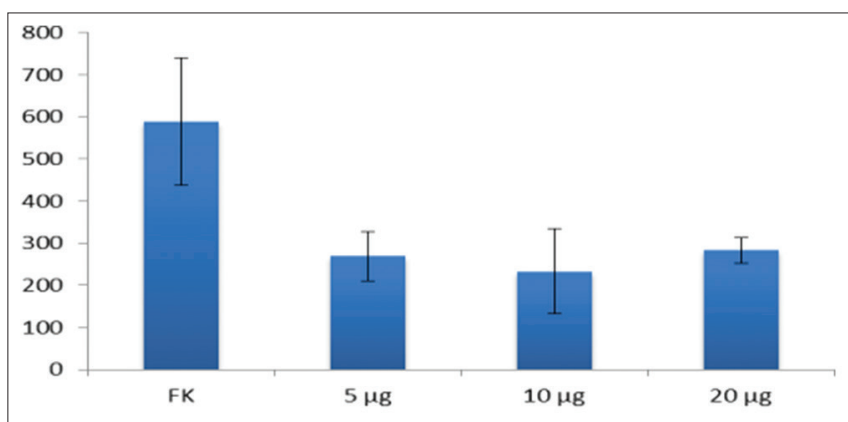

Fig. 2: Effect of T. diversifolia extract on keloid fibroblasts migration activity (\%) at 48 hours. Description: FK = Fibroblasts Keloid, T. diversifolia extract concentration $20 \mu \mathrm{g} / \mathrm{mL} ; 10 \mu \mathrm{g} / \mathrm{mL}$; and $5 \mu \mathrm{g} / \mathrm{mL}$

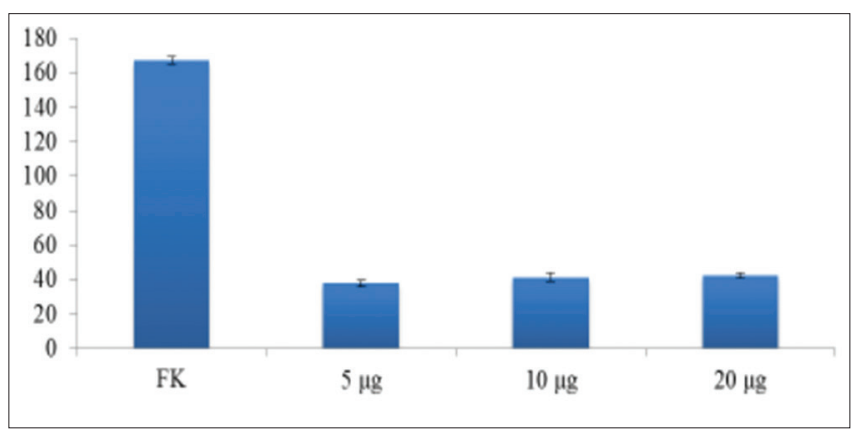

Fig. 3: Effect of T. diversifolia extract on keloid fibroblasts TGF beta 1 expression. Description: FK = Fibroblasts Keloid T. diversifolia extract concentration $20 \mu \mathrm{g} / \mathrm{mL} ; 10 \mu \mathrm{g} / \mathrm{mL}$; and $5 \mu \mathrm{g} / \mathrm{mL}$ 


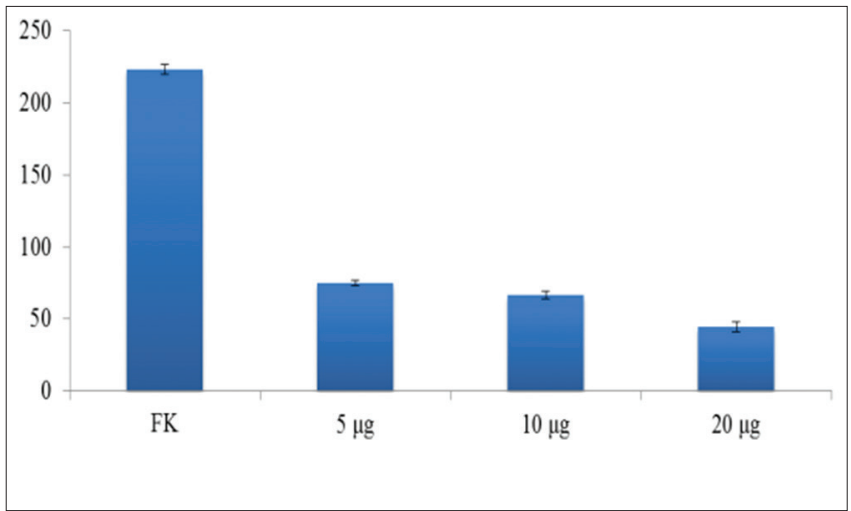

Fig. 4: Effect of T. diversifolia extract on keloid fibroblasts VEGF A expression. Description: FK = Fibroblasts Keloid, $T$ diversifolia extract concentration $20 \mu \mathrm{g} / \mathrm{mL} ; 10 \mu \mathrm{g} / \mathrm{mL}$; and $5 \mu \mathrm{g} / \mathrm{mL}$

through inhibition of keloid fibroblasts and decrease the synthesis of VEGF supernatant concentration groups with optimal concentrations decrease at $20 \mu \mathrm{g} / \mathrm{mL}$ compared to the control group keloid fibroblasts.

\section{DISCUSSION}

Cell migration is an important process to trigger the synthesis of new extracellular matrices and contributes to the wound healing process. On previous research [10], it is stated that fibroblasts taken from keloid tissue by cell culture will show an increase in migration activity. Treatment with ethanolic extract of $T$. diversifolia at a concentration of $20 \mu \mathrm{g} / \mathrm{mL}, 10 \mu \mathrm{g} / \mathrm{mL}$, and $5 \mu \mathrm{g} / \mathrm{mL}$ for $24 \mathrm{~h}$ in this study showed a higher percentage of migration compared to keloid fibroblast untreated, but there was a significant difference at $48 \mathrm{~h}$ after treatment $(\mathrm{p}<0.05)$. This insignificant result is probably caused by decreased activity of mitochondria in fibroblast cells due to reactive oxygen species (ROS) increase. The rise of ROS may cause migration disorders due to changes in the function of tubulin proteins and actin, there is also a change in the growth factor activity of connective tissue growth factor in improving cell adhesion, Rac1 activity and also phosphorylation disturbance c-Jun $\mathrm{N}$-terminal Kinase resulting in migration disorders in fibroblast cells [11,12]. Another study also showed similar keloid fibroblast migration between treated group and control group which might happen because the fibroblast cells are cultured many times which somehow can affect the cells ability to migrate. In addition, the method of scratching and washing of cells after a determined intervention time of $24 \mathrm{~h}$ and $48 \mathrm{~h}$ is done with caution because at the final washing before staining with hematoxylin Mayer many cells is detached. This may affect the migration measurement results using the Image J software.

Keloid formation may involve TGF- $\beta$ expression by some neovascular endothelial cells by producing TGF- $\beta$ autocrine. Gene expression of collagen Type I and IV also increased in keloid tissue. Increased collagen synthesis exceeds the amount of destruction and excess deposition in connective tissue. The collagen connective tissue is produced by fibroblast cells. Disturbed synthesis activities are mediated by changes in growth factor expression [13]. TGF- $\beta$ especially TGF- $\beta_{1}$ is the main cytokines involves in the development of organ fibrosis including keloid. Activation of TGF- $\beta$ signaling in fibroblast cells causing phenotypic changes that may enhance the ability to proliferate and migrate or invasion. Increased TGF- $\beta$ activity in fibroblast cells may also increase the ability to stimulate tissues re-modeling so as to further enhance the growth of keloid tissue. Thus, the inhibition of TGF- $\beta$ pathway is a pathway or indicator of successful keloid therapy [14]. Treatment with ethanolic extract of T. diversifolia on keloid fibroblasts can lower TGF- $\beta 1$ expression significantly $(\mathrm{p}<0.05)$ compared with keloid fibroblasts control. This result which is consistency with the previous study [15] suggest that giving isolates from the butter flower leaf (Nerium indicum Mill.) can significantly lower the level of TGF- $\beta 1$ synthesis compared to the keloid fibroblast control group $(\mathrm{p}<0.01)$ because TGF- $\beta 1$ is the major pathway in keloid formation. In a study [16], it was found that the treatment of Xanthium stramarium and Psoralea corylifolia combined with Ultraviolet A1 radiation can inhibit TGF- $\beta 1$ expression and collagen synthesis in keloid fibroblasts $(\mathrm{p}<0.05)$.

VEGF is a proangiogenesis cytokine that has an important role in normal as well as pathologic conditions of wound healing [17]. VEGF belongs to the group of growth factors have a major role in keloid incident, VEGF-induced angiogenesis directly through mitogenesis endothelial cells and indirectly by increasing the permeability of blood vessels and promotes deposition of extravascular fibrin matrix [18]. VEGF plays an important role in the formation of keloids by changing the extracellular matrix and increased endothelial cell proliferation [19]. VEGF is also important for vascular permeability that promotes neovascularization and cell growth $[20,21]$. Increased expression of VEGF in keloid is showed by the higher amount of VEGF expression in keloid fibroblast group compared with those on treated group. Increased expression of VEGF in keloid fibroblasts is caused by local hypoxia conditions that contributed to hypoxia-inducible factor (HIF-1), a VEGF expression stimulator [22]. Hypoxic conditions generally occur in the inflammatory phase of wound tissue due to disruption of the vascularization process around the wound so that oxygen delivery to other tissues is inhibited. This is exacerbated by the rapid influx of inflammatory cells in the wound tissue. The inflammatory cells play a role in the increase of granulation, re-epitelisasi, and proliferasi [23], cell response to hypoxic conditions is also called the HIF protein expression which is a transcription factor that plays an important role in maintaining the balance of oxygen. Increased of HIF- $1 \alpha$ protein in keloid tissue result in increased expression of TGF- $\beta$, thrombospondin- 1 , plasminogen activator inhibitor-1, and VEGF which play a major role in driving the fibroblast proliferation [22]. Fibrosis in keloid tissue is caused by increased of exogenous and endogenous VEGF in keloid fibroblasts. Exogenous VEGF will increase the VEGF receptors, whereas endogenous VEGF will increase with increased transcription factor VEGF and insulin-like growth factor 1 in tissues fibroblasts keloid [19]. VEGF as a pro-angiogenic growth factor increase the keloid tissue angiogenesis that chronic inflammation occurs and persistent increase fibroblast proliferation. Ethanolic extract of T. diversifolia treatment of various concentrations $(20 ; 10$; and 5$) \mu \mathrm{g} / \mathrm{mL}$ showed lower VEGF expression compared with those in keloid fibroblast control, with optimal decrease occurring at the concentration $20 \mu \mathrm{g} / \mathrm{mL}$ with VEGF expression value of $44.82 \mathrm{pg} / \mathrm{mL}$ when compared with keloid fibroblast group $(\mathrm{p}<0.05)$. The lowest VEGF expression is showed in the concentration of the ethanolic extract of T. diversifolia $20 \mu \mathrm{g} / \mathrm{mL}$ which is the highest treatment concentration. VEGF expression is optimal at that concentration. Another research results that VEGF is released in large amounts from degranulating platelets, and it is present in wound fluid, particularly early after injury. The expression of VEGF related antigen, a marker of vascular endothelial cell, a marker of proliferation, in the wounds showed that there was an increase in the number of new capillary sprouts in the three evidence-based practice (EBP) gel groups at varied extent, especially in 75\% EBP gel groups, compared with that in control group on day 12 and day 16 after wounding [24]. Other research also concluded that ethyl acetate fraction of Andrographis paniculata and doxorubicin combination increase apoptosis and decrease VEGF protein expression of mice fibrosarcoma cells [25].

Based on the results of VEGF expression, ethanolic extract of T. diversifolia might inhibit the proliferation of keloid fibroblasts cells through the inhibition of the expression of VEGF and specifically inhibit the formation of a transcription factor of endogenous VEGF in keloid fibroblasts. VEGF is abundant in the dermis underlying keloids. In vitro studies have shown that VEGF is expressed at high levels in keloid fibroblasts derived from normal skin fibroblast [26].

\section{CONCLUSION}

Ethanolic extract of $T$. diversifolia can decrease migration activity on keloid fibroblast at $24 \mathrm{~h}$ in concentration $10 \mu \mathrm{g} / \mathrm{mL}$. The TGF- $\beta 1$ 
expression of Keloid fibroblast in $5 \mu \mathrm{g} / \mathrm{mL}$ ethanolic extract of T. diversifolia was lower compared to those on the control group. The expression of VEGF keloid fibroblast in all concentration ethanolic extract of $T$. diversifolia was lower compared to those on the control group.

\section{ACKNOWLEDGMENT}

This research was supported by the UGM PUPT 2017 grant. We are also gratefull to the member of the research project Arief and Elvira for the technical assistance.

\section{AUTHORS' CONTRIBUTION}

MSH contributed to drafting the manuscript, research design, data collection, analysis, and interpretation. DAAN and AB contributed to the revision of the manuscript. All the authors read and approved the final manuscript.

\section{CONFLICTS OF INTEREST}

Authors declare that there are no conflicts of interest.

\section{REFERENCES}

1. Sund B. New Developments in Wound Care. London: PJB Publications; 2000. p. 1255 .

2. Bayat A, McGrouther DA, Ferguson MW. Skin scarring. BMJ 2003;326:88-92

3. SeoBF,LeeJY,JungSN.Modelsofabnormalscarring.BiomedResInt2013; 2013:423147.

4. Muneuchi G, Suzuki S, Onodera M, Ito O, Hata Y, Igawa HH, et al. Long-term outcome of intralesional injection of triamcinolone acetonide for the treatment of keloid scars in asian patients. Scand J Plast Reconstr Surg Hand Surg 2006;40:111-6.

5. Wahyuningsih MS, Wirohadidjojo YW, Hidayat R, Sadid A. Antifibrotic effect of standardized ethanol extract of Tithonia diversifolia (Hemsley) A. Gray on keloid fibroblasts. Int J Pharmacog Phytochem Res 2015;7:642-7.

6. Wahyuningsih MS, Wijayanti MA, Budiyanto A, Hanafi M. Isolation and identification of potential cytotoxic compound from Kembang bulan Tithonia diversifolia (Hemsley) A. Gray leaves. Int J Pharm Pharm Sci 2015;7:298-301

7. Ranti I. Antifibrotic Effect of Tagitinin C Isolated from the Leaf of Tithonia diversifolia (Hemsley) A. Gray Thesis. Yogyakarta: Universitas Gadjah Mada; 2014.

8. Liang Y, Niederstrasser H, Edwards M, Jackson CE, Cooper JA. Distinct roles for CARMIL isoforms in cell migration. Mol Biol Cell 2009;20:5290-305

9. Straatman K. Wound healing assay. J Mol Biol Cells 2008;10:1-4

10. Fujiwara M, Muragaki Y, Ooshima A. Keloid-derived fibroblasts show increased secretion of factors involved in collagen turnover and depend on matrix metalloproteinase for migration. Br J Dermatol 2005;
153:295-300.

11. Chen Y, Abraham DJ, Shi-Wen X, Pearson JD, Black CM, Lyons KM, et al. CCN2 (connective tissue growth factor) promotes fibroblast adhesion to fibronectin. Mol Biol Cell 2004;15:5635-46.

12. Xuan YH, Huang BB, Tian HS, Chi LS, Duan YM, Wang X, et al. High-glucose inhibits human fibroblast cell migration in wound healing via repression of bFGF-regulating JNK phosphorylation. PLoS One 2014;9:e108182

13. Nemeth AJ. Keloids and hypertrophic scars. J Dermatol Surg Oncol 1993;19:738-46

14. Yang L, Pang Y, Moses HL. TGF-beta and immune cells: An important regulatory axis in the tumor microenvironment and progression. Trends Immunol 2010;31:220-7

15. Dachlan I. Effect of 5 $\alpha$-Oleandrin Isolated from Nerium indicum Mill as Antikeloid: Study on Fibroblast keloid in vitro Disertation. Yogyakarta: Universitas Gadjah Mada; 2015.

16. Park SY, Park JY, Kim CH, Kang SU, Kim JH, Bark KM, et al. Effects of Xanthium stramarium and Psoralea corylifolia extracts combined with UVA1 irradiation on the cell proliferation and TGF- $\beta 1$ expression of keloid fibroblasts. Ann Dermatol 2013;25:304-9.

17. CarmelietP,JainRK.Angiogenesisincancerandotherdiseases.Nature2000; 407:249-57.

18. Chau CH, Clavijo CA, Deng HT, Zhang Q, Kim KJ, Qiu Y, et al. Etk/ Bmx mediates expression of stress-induced adaptive genes VEGF, PAI 1, and iNOS via multiple signaling cascades in different cell systems. Am J Physiol Cell Physiol 2005;289:C444-54

19. Wu WS, Wang FS, Yang KD, Huang CC, Kuo YR. Dexamethasone induction of keloid regression through effective suppression of VEGF expression and keloid fibroblast proliferation. J Invest Dermatol 2006; 126:1264-71.

20. Zhang Q, Wu Y, Ann DK, Messadi DV, Tuan TL, Kelly AP, et al. Mechanisms of hypoxic regulation of plasminogen activator inhibitor-1 gene expression in keloid fibroblasts. J Invest Dermatol 2003; 121:1005-12.

21. Bosco MC, Puppo M, Blengio F, Fraone T, Cappello P, Giovarelli M, et al. Monocytes and dendritic cells in a hypoxic environment: Spotlights on chemotaxis and migration. Immunobiology 2008;213:733-49.

22. Distler JH, Jüngel A, Pileckyte M, Zwerina J, Michel BA, Gay RE, et al. Hypoxia-induced increase in the production of extracellular matrix proteins in systemic sclerosis. Arthritis Rheum 2007;56:4203-15.

23. Gira AK, Brown LF, Washington CV, Cohen C, Arbiser JL. Keloids demonstrate high-level epidermal expression of vascular endothelial growth factor. J Am Acad Dermatol 2004;50:850-3.

24. Sukardiman R, Khotib J. The increasing of VEGF expression and reepithelialization on dermal wound healing process after treatment of banana peel extract (Musa acuminata Colla). Int J Pharm Pharm Sci 2014;6:427-30

25. Suharjono S, Balqianur T. The role of ethyl acetate fraction of Andrographis paniculata and doxorubicin combination toward the increase of apoptosis and decrease of VEGF protein expression of mice fibrosarcoma cells. Int J Pharm Pharm Sci 2015;7:347-50.

26. PlateKH,WarnkePC.Vascularendothelialgrowthfactor.JNeurooncol1997; $35: 365-72$ 